\title{
Content of Prussic Acid and Production of Sorghum Brown Midrib by Adding Urea Fertilizer and Extending Harvesting Time
}

\author{
Nafiatul Umami*, Nofi Isnaini and Bambang Suhartanto \\ Faculty of Animal Science, Gadjah Mada University, Yogyakarta, Indonesia \\ *Corresponding author email: nafiatul.umami@ugm.ac.id
}

\begin{abstract}
This study aimed to determine the effect of adding urea fertilizer $(0,50$ and $100 \mathrm{~kg} / \mathrm{ha})$ and harvesting time (50, 80 and days) on prussic acid content and production of the brown midrib (BMR) sorghum plants. This study design was a completely randomized factorial $3 \times 3$. The variables measured were prussic acid content, fresh yield, the production of dry matter (DM) and organic matter (OM). The results showed that prussic acid content increased highly significant after the urea addition. The fresh yield of BMR sorghum was highest in the fertilization of $50 \mathrm{~kg} / \mathrm{ha}$ and at the harvesting time 80 days. The highest DM was obtained from $0 \mathrm{~kg} / \mathrm{ha}$ fertilization and 110 day harvesting time. OM production of the highest is the addition of fertilizer $0 \mathrm{~kg} / \mathrm{ha}$ and at the harvesting time on 80 days. It was concluded that 80 -day harvesting time produced optimum sorghum BMR and urea addition up to $100 \mathrm{~kg} /$ ha did not affect prussic acid content, fresh yield, DM and OM.
\end{abstract}

Keywords: urea fertilizer, harvesting time, prussic acid, production, BMR sorghum

\begin{abstract}
Abstrak. Penelitian ini bertujuan untuk mengetahui pengaruh penambahan pupuk urea pada level $(0,50$ dan 100 $\mathrm{kg} / \mathrm{ha}$ ) dan umur potong (50, 80 dan 110 hari) terhadap kandungan asam prusik dan produksi tanaman sorgum brown midrib (BMR). Penelitian ini menggunakan rancangan acak lengkap pola faktorial $3 \times 3$. Variabel yang diamati adalah kandungan asam prusik, produksi segar, produksi bahan kering (BK) dan produksi bahan organik (BO). Hasil penelitian menunjukkan bahwa kandungan asam prusik secara signifikan dipengaruhi oleh penambahan pupuk urea dan umur potong. Produksi segar tanaman sorgum BMR tertinggi adalah pada pemupukan $50 \mathrm{~kg} / \mathrm{ha}$ dan pada umur potong 80 hari. Produksi BK tertinggi pada pemupukan $0 \mathrm{~kg} / \mathrm{ha}$ dan umur potong 110 hari. Produksi BO tertinggi adalah pada penambahan pupuk $0 \mathrm{k} / \mathrm{ha}$ dan pada umur potong 110 hari. Dari hasil penelitian dapat disimpulkan bahwa umur potong secara signifikan berpengaruh terhadap kandungan asama prusik, produksi segar, produksi BK dan BO. penambahan pupuk urea hingga level $100 \mathrm{~kg} / \mathrm{ha}$ tidak berpengaruh terhadap produksi segar, produksi serta kandungan BK dan BO.
\end{abstract}

Kata kunci: pupuk urea, umur potong, asam prusik, produksi, sorgum BMR

\section{Introduction}

Sorghum is a highly adaptable forage against dry environmental conditions and able to thrive in low-nutrient and barren soil. Sorghum is one of the world important crops; adaptive crops to various agronomic and environmental conditions, particularly areas with low rainfall or limited access to irrigation water. The beneficial properties of sorghum plants enable for forage sorghum fodder. Technology has advanced genetic engineering to produce high quality crops. Brown midrib is one product of genetic mutation of some plants, and sorghum brown midrib contains low lignin. Lignin content is a limiting factor to forage digestibility of livestock.
Fertilizer to increase production and quality of high acid in sorghum prusik; therefore, it requires a proper handling. An increased nitrogen fertilization may improve prussic acid production (Sher et al., 2012). Prussic acid or cyanide ( $\mathrm{HCN}$ ) is commonly found in plant stress and formed by the enzymatic reaction when growth is impaired because the environmental conditions are not suitable as drought. Prussic acid found in plant tissue sorghum is relatively high compared to other toxic species. Prussic acid is prominent in younger than than old plants, and in leaves than in the trunk. Prussic acid concentration decreases as the sorghum grow higher and older (Jennings, 2013). 
Accordingly, we need to investigate the effect of adding urea fertilizer and extending harvesting time against prussic acid content to increase sorghum BMR production with low prussic acid.

\section{Materials and Methods}

This study used BMR sorghum seeds from Johnny seeds USA. Experiment materials included urea fertilizer, organic fertilizer derived from PIAT UGM, soil in the field experiment Forage and Pasture Laboratory Faculty of Animal Science, polybag with a diameter of $25 \mathrm{~cm}$, digital scales, analytical balance, $55^{\circ} \mathrm{C}$ and $105^{\circ} \mathrm{C}$ ovens, $550^{\circ} \mathrm{C}$ furnaces, analysis kit for prussic acid, DM and OM.

The study was designed in a completely randomized $3 \times 3$ factorial. Factor 1 was urea fertilizer additions, i.e. 0 (P1), 50 (P2) and 100 (P3) $\mathrm{kg} / \mathrm{ha}$. Factor 2 was harvesting times, i.e. 50 (U1), 80 (U2) and 110 (U3) day. Each treatment had 3 replications, making up 27 units polybag in total.

Land used is ground parts of top soil or approximately $15 \mathrm{~cm}$ from the ground. A total of $7 \mathrm{~kg}$ soil and $3 \mathrm{~kg}$ organic manure (as fertilizer base) were mixed, put into a $25-\mathrm{cm}$ diameter polybag, and let sit for approximately seven days to make planting medium. Four $5-\mathrm{cm}$ holes were punched in one polybag, each filled with one sorghum grain and covered with soil medium. The space between polybags was $0.5 \mathrm{x}$ $0.5 \mathrm{~m}$.

Thirty days after seed planting, the urea $(0$, 50 and $100 \mathrm{~kg} / \mathrm{ha}$ ) was embedded in the ground $\pm 5 \mathrm{~cm}$ from the planting hole to avoid direct contact between cultivated fertilizer and the plant. Thinning was conducted 15 days after seed planting by leaving two major crops in each polybag. Every two days, the plants were watered $(500 \mathrm{ml}$ or according to field capacity), and the soil was loosened and weeded carefully to avoid bruising the BMR sorghum plant roots.

The plants were harvested three times on 50,80 and 110 days by cutting the sorghum
$15 \mathrm{~cm}$ above the ground to measure the production of fresh forage sorghum BMR. The freshly harvested BMR sorghum leaves were finely cut and blended for prussic acid content. The whole BMR sorghum crop (stems and leaves) were chopped into small pieces, packed in a paper bag and stored in a $55^{\circ} \mathrm{C}$ oven for approximately 3 days to obtain dry weight. The sample was dried, milled in a Willey mill with 1 $\mathrm{mm}$ porosity, then analyzed to determine DM and $\mathrm{OM}$.

The observed variables were prussic acid content, fresh yield, DM and OM. The yield was calculated by weighing the plant (g/polybag) and DM was measured from the weight of the plant at harvest ( $\mathrm{g} /$ polybag) then multiplied by DM percentage. DM production was multiplied by OM content to obtain OM production.

The prussic acid content and production (fresh yield, DM and OM) were subjected to an analysis of variance in a completely randomized design with a $3 \times 3$ factorial. Any significant difference across treatments were analyzed using a Duncan's Multiple Range Test (DMRT). All data were analyzed with SPSS 16.0.

\section{Results and Discussions}

\section{Prussic Acid}

Prussic acid content (ppm) of BMR sorghum plants treated with additional urea and extended harvesting time was presented in Table 1. An increased urea level in each treatment could improve prussic acid content. The result showed that additional urea fertilizer significantly affected prussic acid content $(P<0.01$; the higher the $N$ fertilizer, the higher the prussic acid content.

Similarly, Purnomohadi (2005) stated that prussic acid increase was linear with $\mathrm{N}$ fertilizer dose. Nitrogen is an essential component of amino acids, while the prussic acid is a compound of plant secondary metabolites derived from amino acids.

The highest prussic acid content (73.33 piece ppm) was obtained from $100 \mathrm{~kg}$ urea/ha 
Nafiatul Umami et al./Animal Production. 21(2):93-97, 2019

Accredited by Kemenristek Dikti No 32a/E/KPT/2017. ISSN 1411-2027

addition and harvested on 80 days. Therefore, prussic acid content was within the safe level for livestock. Shreve (2002) stated that the recommended maximum safe level of prussic acid in plants was 300-500 ppm.

Harvest at 110 days obtained the lowest prussic acid content. It showed that harvesting time significantly affected prussic acid content $(P<0.05)$ because the older the plant, the lower the prussic acid content. Similarly, Jennings (2013) stated that prussic acid content in young plants was higher than the old plant. Prussic acid concentration decreased as high and growth stages. Young plants sorghum with a high prussic acid content should not be cut if the plant is higher than $60,96 \mathrm{~cm}$ or below 45 , $72 \mathrm{~cm}$ (Whittier, 2011). Stunted growth causes prussic acid accumulation in plants.

Statistical analysis result showed that commercial feed did not significantly affect $(P>0.05)$ total hemoglobin of 35-day-old broiler chickens, and the leukocyte was within the normal range, i.e. $6.85 \pm 0.87$ to $7.27 \pm 0.55$ $\mathrm{g} / \mathrm{dl}$. Crude protein level in the commercial feed was $21.00-23.00 \%$ (starter) and $19.00-21.00 \%$ (finisher), which was sufficient for the chickens. Protein, especially amino acid glycine and $\mathrm{Fe}$ mineral, was the building blocks for hemoglobin; therefore, the total hemoglobin is maintained by the combined protein and Fe.

Analysis of variance result showed that the addition of urea fertilizer and harvesting time showed no significant interaction of the prussic acid content.

Harvesting time significantly affected sorghum BMR fresh yield $(P<0.05)$. The older the plant, the higher the plant biomass. It was in accordance with Abbassi et al. (2012) that the Amaranth plants at milk phase contained the highest nutrient content. An increased harvesting positively affected fresh production of Amaranth plants. After reaching the peak point, plant growth and the subsequent production would decline. Puteri (2015) mentioned that sorghum strain PATIR production peaked on 95 days and declined on 105 days. Biomass production increases with the age of the plant.

Analysis of variance result showed that the interaction between urea addition and harvesting time did not significantly impact the fresh yield. Furthermore, $100 \mathrm{~kg} / \mathrm{ha}$ fertilizer dosage had not impacted the yield. It was contrary to a literature claim that higher

Table 1. Content of prussic acid (ppm)

\begin{tabular}{ccccc}
\hline \multirow{2}{*}{ Urea } & \multicolumn{3}{c}{ Harvesting time } & \multirow{2}{*}{ Average } \\
\cline { 2 - 4 } & U1 & U2 & U3 & $39.78^{\mathrm{a}}$ \\
P1 & 44.67 & 40.00 & 34.67 & $50.89^{\mathrm{b}}$ \\
P2 & 57.33 & 54.33 & 41.00 & $69.67^{\mathrm{c}}$ \\
\hline P3 & 71.00 & 73.33 & 64.67 & 53.44
\end{tabular}

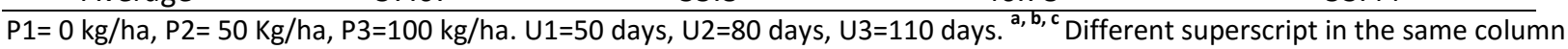
shows the difference $(P<0.05){ }^{p, q}$ Different superscript in the same row indicate differences $(P<0.05)$

Table 2. Average fresh yield BMR sorghum (g/polybag)

\begin{tabular}{ccccc}
\hline \multirow{2}{*}{ Urea } & \multicolumn{3}{c}{ Harvesting time } & \multirow{2}{*}{ Average $^{\mathrm{ns}}$} \\
\cline { 2 - 4 } & $\mathrm{U} 1$ & $\mathrm{U} 2$ & $\mathrm{U} 315.00$ & 273.00 \\
P1 & 159.67 & 344.33 & 315.67 & 285.56 \\
P2 & 193.67 & 347.33 & 322.00 & 265.89 \\
\hline P3 & 203.33 & 272.33 & $317.56^{\mathrm{b}}$ & 274.81 \\
\hline
\end{tabular}

$\mathrm{P} 1=0 \mathrm{~kg} / \mathrm{ha}, \mathrm{P} 2=50 \mathrm{Kg} / \mathrm{ha}, \mathrm{P} 3=100 \mathrm{~kg} / \mathrm{ha}$. U1=50 days, U2=80 days, U3=110 days. ${ }^{\text {a,b }}$ Different superscript in the same row indicate differences $(P<0.05)$. ${ }^{\text {ns }}$ Non-significant 
Nafiatul Umami et al./Animal Production. 21(2):93-97, 2019

Accredited by Kemenristek Dikti No 32a/E/KPT/2017. ISSN 1411-2027

fertilizer for older plants would affect the crop because plant at certain age requires excess nutrients.

\section{Dry Matter Production (DM)}

The average DM production of BMR sorghum plants with additional urea fertilizer and harvesting time was presented in Table 3. Table 3 shows that DM level decreased with the addition of urea. Therefore, urea addition did not significantly affect BMR sorghum DM; however, the 80-day crops fertilized with $100 \mathrm{~kg} / \mathrm{ha}$ urea obtained the highest yield. Similarly, Purnomohadi (2005) stated that 30 $\mathrm{kg} / \mathrm{ha}$ urea could improve production. Buckman and Brady (1982) reported that plants need a large quantity of nitrogen, so plant growth may be hampered if nitrogen is not available. Growth accumulation was expressed in DM production.

Harvesting time plants significantly affected DM production of sorghum BMR $(P<0.01)$. The longer the plants life would extend the photosynthesis process to carry out each life stage. It was in accordance with Koten (2012) that DM of the upper part of the plant increases as the cutting days are extended because the longer photosynthesis process would accumulate the photosynthesis product in the plant tissues.

Analysis of variance result showed that the addition of urea and harvesting time did not significantly affect DM production of sorghum BMR.

\section{Organic Matter Production (OM)}

The average $\mathrm{OM}$ production of BMR sorghum plants treated with the addition of fertilizing and harvesting time was presented in Table 4. The result showed that additional urea fertilizer did not significantly affect OM production of BMR sorghum. Urea addition up to $100 \mathrm{~kg} / \mathrm{ha}$ cannot be fully utilized by the plant. Nitrogen is needed by plants in high amounts of essential components primarily for the synthesis of organic material making up the amino acids and proteins, nucleic acids, hormones and chlorophyll. Organic material in crops affected the availability of organic matter in the soil (Bassegio et al., 2013). Plant harvesting time significant affected $O M$ production of sorghum BMR $\quad(\mathrm{P}<0.05)$. Carbohydrate content of sorghum plants differ in each phase of growth (Bian et al., 2006). Huston and Pinchak (1991) stated that that the protein and fat content would decrease when

Tabel 3. Average DM production of BMR sorghum (gram/polybag)

\begin{tabular}{|c|c|c|c|c|}
\hline \multirow{2}{*}{ Urea } & \multicolumn{3}{|c|}{ Harvesting time } & \multirow{2}{*}{ Average $^{\text {ns }}$} \\
\hline & U1 & U2 & U3 & \\
\hline P1 & 22.26 & 69.73 & 152.15 & 81.38 \\
\hline P2 & 32.16 & 71.15 & 132.11 & 78.47 \\
\hline P3 & 28.91 & 78.39 & 120.89 & 76.07 \\
\hline Average & $27.78^{\mathrm{a}}$ & $73.09^{b}$ & $135.05^{c}$ & 78.64 \\
\hline
\end{tabular}

$\mathrm{P} 1=0 \mathrm{~kg} / \mathrm{ha}, \mathrm{P} 2=50 \mathrm{Kg} / \mathrm{ha}, \mathrm{P} 3=100 \mathrm{~kg} / \mathrm{ha}$. U1=50 days, U2=80 days, U3=110 days

$a, b, c$ Different superscripts within row indicate differences $(P<0.05)$. ${ }^{\mathrm{ns}}$ Non-significant

Table 4. Average OM production BMR sorghum (g/polybag)

\begin{tabular}{ccccc}
\hline \multirow{2}{*}{ Urea } & \multicolumn{3}{c}{ Harvesting time } & \multirow{2}{*}{ Average $^{\text {ns }}$} \\
\cline { 2 - 4 } & U1 & U2 & U3 & 70.22 \\
P1 & 17.56 & 59.12 & 133.97 & 66.80 \\
P2 & 25.40 & 59.73 & 115.28 & 64.23 \\
\hline P3 & 23.59 & 64.99 & 104.11 & 67.08 \\
\hline
\end{tabular}

$\mathrm{P} 1=0 \mathrm{~kg} / \mathrm{ha}, \mathrm{P} 2=50 \mathrm{~kg} / \mathrm{ha}, \mathrm{P} 3=100 \mathrm{~kg} / \mathrm{ha}$. U1=50 days, U2=80 days, U3=110 days

$\mathrm{a}, \mathrm{b}, \mathrm{c}$ Different superscript in the same row indicate differences $(\mathrm{P}<0.05) .{ }^{\mathrm{ns}}$ Non significant 
Nafiatul Umami et al./Animal Production. 21(2):93-97, 2019

Accredited by Kemenristek Dikti No 32a/E/KPT/2017. ISSN 1411-2027

the optimum growth further increased the content of crude fiber and lignin.

Analysis of variance result showed that the addition of urea and harvesting time showed no significant effect on $\mathrm{OM}$ production of $\mathrm{BMR}$ sorghum.

\section{Conclusions}

The results of this study concluded that adding urea fertilizer significantly affected the content of prussic acid. Brown midrib sorghum plants were cut 80 days after planting, and the addition of $50 \mathrm{~kg} / \mathrm{ha}$ urea had produced the highest fresh yield. The highest DM and OM were obtained at 110 days with $100 \mathrm{~kg}$ urea/ha.

\section{References}

Abbassi, D., Y. Rouzbehan dan J. Rezaei. 2011. Effect Of Harvest Date And Nitrogen Fertilization Rate On The Nutritive Value Of Amaranth Forage (Amaranthus hypochondriacus). Animal Feed Sience and Technology. 171 (2012) 6-13.

Bassegio, D., R. F., Santos, E. de Oliveira, I. Buckman, D, Secco and S, N, M, de Souza. 2013. Effect Of Nitrogen Fertilization And Cutting Age On Yield Of Tropical Forage Plants. African Journal of Agricultural Research. 8(16): 1427-1432.

Bian, Y. I., Y. Seiji, I. Maiko and H. W. CAI. 2006. QTLS for sugar content of stalk in sweet sorghum (Sorghum bicolor L. Moench). Agricultural Sciences in China 2006. 5(10): 736-744
Buckman, H. O. dan N. C. Brady. 1982. Ilmu Tanah. Translated by : Prof. Dr. Soegiman. Penerbit Bhratara Karya Aksara. Jakarta.

Huston, J. E. and W. E. Pinchak. 1991. Range Animal nutrition. In: Grazing Management: An ecological perspective. pp.27-64.

Jennings, J. 2013. Prussic Acid. University of Arkansas Cooperative Extension Service Printing Services. FSA3069PD112RV.

Koten, B, B., R. D. Soetrisno, N. Ngadiyono, and B. Suwignyo. 2012. Produksi Tanaman Sorgum (Sorghum bicolor (L.) Moench) Varietas Lokal Rote Sebagai Hijauan Pakan Ruminansia Pada Umur Panen Dan Dosis Pupuk Urea Yang Berbeda. Buletin Peternakan 36(3): 150-155.

Purnomohadi, M. 2005. Peranan Umur Pemotongan Dan Pemupukan Nitrogen Terhadap Mutu Hijauan Pakan Sorgum Manis (Sorghum bicolor L. Moench. Media Kedokteran Hewan. (21):3.

Puteri, R. E., P. M. H. D. Karti, L. Abdullah, and Supriyanto. 2015. Productivity and nutrient quality of some sorghum mutant lines at different cutting ages. Media Peternakan. (2):132-137.

Sher, A., M. Ansar, F. U. Hassan, G. Shabbir, and M. A. Malik. 2012. Hydrocyanic acid content variation amongst sorghum cultivars grown with varying seed rates and nitrogen levels. Int. J. Agric Biol. (14): 720-726.

Shreve, B. 2002. Management Of Nitrate And Prussic Acid In Forage Crops. Proceding, Western Alfafa and Forages Conference, 11-13 Desember 2002.

Whittier, J. C. 2011. Prussic acid poisoning. Livestoct Series. Fact sheet. 1612. Colorado state University. 